\title{
APONTAMENTOS SOBRE DIFERENTES REPRESENTAÇÕES DO IMIGRANTE JUDEU EM HACER LA AMÉRICA E NA TRILOGÍA DE ENTRE RÍOS
}

\section{NOTES ON DIFFERENT REPRESENTATIONS OF THE JEWISH IMMIGRANT IN HACER LA AMÉRICA AND IN THE TRILOGÍA DE ENTRE RÍOS}

Fernanda Palo Prado*

Resumo: Este artigo pretende discutir duas representações da figura do imigrante judeu: uma delas é a presente na obra Hacer la América (Fazer a América, 1984) de Pedro Orgambide e a outra é a presente na Trilogía de Entre Ríos (2006) de Perla Suez, principalmente por meio das relações estabelecidas com a novela El Arresto (A Prisão). As questões que mobilizam essa proposta são: como cada um desses textos constrói sua visão das colônias judaicas no litoral argentino? Como cada um deles se relaciona com a imagem do gaucho judío, construída por Gerchunoff? Como cada um explora as questões do ser estrangeiro e da memória? Como se dá a ida à cidade desses personagens gauchos e judeus? E, por fim, como são narradas as tensões e a violência relacionadas ao grupo de imigrantes judeus no início do século XX na Argentina?

Palavras-chave: Gauchos judios. Imigrantes. Representação.

\begin{abstract}
This presentation aims to discuss two representations of the figure of the Jewish immigrant: one of them is in Hacer la América (1984), a novel by Pedro Orgambide and the other is in the Trilogia de Entre Ríos (2006) by Perla Suez, mainly through the shortstory "El arresto". The questions that mobilize this proposal are: how does each of these texts build its view of the Jewish colonies on the Argentine coast? How does each of them relate to the image of the Jewish gaucho, built by Gerchunoff? How does each one explore the issues of foreignness and memory? How do these gauchos and Jews go to the city? And finally, how are the tensions and violence related to the group of Jewish immigrants at the beginning of the 20th century in Argentina narrated?
\end{abstract}

Keywords: Jewish gaúchos. Immigrants. Representation.

Para iniciar esta discussão a respeito das representações construídas do imigrante judeu em Pedro Orgambide e em Perla Suez faz-se necessária uma breve sinopse de cada obra e dos contextos nos quais elas foram escritas que, tendo um conhecimento ainda que sumário de cada uma delas, será possível acompanhar essa proposta de leitura comparada.

${ }^{*}$ FFLCH/USP, São Paulo, Brasil, doutoranda de Pós Graduação em História Social. Email: <ppradofe @usp.br>. 
De um lado, temos Hacer la América, uma obra de Pedro Orgambide (1929-2003), que foi publicada em Buenos Aires em 1984, apesar de ter sido escrita previamente no período de exílio do escritor no México, de 1974 a 1983. Trata-se de um romance sobre a formação da identidade nacional argentina, não livre de disputas, entre grosso modo, os nascidos na Argentina e os imigrantes - e seus descendentes, chegados de diferentes partes do mundo. Neste romance, estão as vozes de diversos imigrantes - pela ordem de aparição: italianos, espanhóis e judeus russos que vão se misturando com a fala gaucha dos arrabaldes e a rioplatense das orillas somada também a dos descendentes das primeiras levas imigratórias. Lemos o passar do tempo que se inicia com a chegada de um italiano calabrês em fins do século XIX, o desenrolar da história argentina e o processo de desenvolvimento da cidade de Buenos Aires por meio da narração do cotidiano dessa multidão anônima que, a partir do trabalho da memória, narra cada qual a sua estória que culmina no desfecho com a semana trágica do verão de 1919.

De outro, temos a Trilogía de Entre Ríos de Perla Suez (1947 -), publicada em 2006. Essa obra é composta por "tres novelas cortas, o tres cuentos largos", como afirma Saccomanno no prólogo. A primeira novela ou, como está no prólogo, romance curto é Letargo que havia sido publicada em 2000 e narra o retorno de uma mulher adulta à vila em que passou a infância de forma que diferentes temporalidades se encontram e se entrelaçam: a da criança - um certo passado -, a do retorno - um certo presente - e a da memória. El arresto, publicada originalmente em 2001, narra a trajetória de uma família cujo casal judeu emigra para a Argentina fugido dos pogroms e ruma para o interior trabalhar em um campo de arroz. A esposa morre na sequência do nascimento do terceiro filho, Lucien, que - circundado por mortes e traições - emigra para a cidade para fazer a faculdade de medicina, onde é preso e torturado durante a Semana Trágica de 1919. Complot é a novela que completa a trilogia, originalmente publicado em 2004, nela está a história de um imigrante judeu que enriquece no interior argentino, depois de viver escondendo seu passado. A intriga é movida por interesses ingleses nas "riquezas" da região: no gado contrabandeado, nas linhas de trem e na esposa do estancieiro judeu.

Este artigo parte do ponto em que as obras se distanciam ao propor representações oriundas da reconstrução do mito do gaucho judio, que se desprende da construção feita por Alberto Gerchunoff, em sua obra de 1910, Los gaúchos judíos e parte, então, da literatura para se inscrever

\footnotetext{
${ }^{1}$ SACCOMANNO, 2006, p.10.
} 
no imaginário social e em certa memória social. Essa figura é, então, formada a partir da diáspora judaica para a Argentina e sua posterior ida às colônias do interior. Como prosseguimento, refletimos sobre as aproximações entre as representações propostas nessas obras por Orgambide e Suez que versam um campo mais amplo que tanto tange as propostas de hibridização da forma narrativa, quanto a propostas temáticas também relacionadas a uma certa tradição judaica, como a presença de questões sobre a memória, a estrangereidade e o esquecimento e, ainda, como a ida à cidade e a violência.

\section{Distanciamentos}

Nessas duas obras, o maior distanciamento está relacionado à uma revisita e uma reconstrução do mito do gaucho judío, que é uma expressão que foi imortalizada por Alberto Gerchunoff com a obra Los gaúchos judíos. Essa obra de Gerchunoff foi publicada no ano das comemorações do centenário da independência argentina, da declaração do cabildo aberto. Segundo Sosnowski, trata-se de um texto fundacional da literatura judaica-argentina (ou, ainda, da literatura judaica latino-americana), "porque apareció en 1910 para sumarse a las celebraciones del Centenario, porque articuló los ejes en torno a los cuales se dirime la integración del inmigrante que siempre estará signado por lo minoritario, porque se adelantó a la consideración de lo nacional". ${ }^{2}$ Em Los gauchos judíos está a paisagem, a possibilidade de paz e de sobrevivência proporcionada pela imigração a esse grupo proveniente, em sua maioria, do leste europeu.

Alberto Gerchunoff (1884-1950) imigrou criança e com a família passou parte da infância em uma colônia agrícola em Entre Ríos. Seu pai morreu assassinado por um gaucho e ainda jovem rumou para a cidade de Buenos Aires. Nesta sua obra que mescla ficção, ensaio e política, com reflexões sobre o desterro, Gerchunoff busca um certo pertencimento, uma certa voz coletiva a qual pertencer localizando-a também como parte da nação argentina que se configura por meio dessas vozes dissonantes provenientes do processo de imigração.

Com esta obra em mente, por um lado, temos o romance Hacer la América de Pedro Orgambide. Nele, a principal família representante da tradição judaica é a dos Burtfichtz. Essa família emigra para Buenos Aires, passa alguns dias na casa de um parente distante e ruma para

\footnotetext{
${ }^{2}$ SOSNOWSKI, 2000, p. 263.
} 
uma colônia agrícola. Depois que a partida é anunciada, um fragmento irrompe e, sem apresentações e sem identificação da voz que a narra, é contada a ida de um grupo de judeus ao interior, à terra adentro:

Yo lo vi, señor; yo vi a esos infelices caminando junto a las vías del tren, mendigando un pedazo de pan. Se lo juro por ésta. Iban para Entre Ríos, a unos campos de los que nadie sabía dar razón. Pero ello, no lo va a creer, seguían caminando detrás de un viejo que cantaba y leía su Libro y les hablaba de Dios. (...) Yo los vi caminar, como le digo, durante días y días por el campo. No los pude ayudar, no mucho, porque yo también andaba perseguido. No, a ellos no les perseguía la partida. La desgracia, no más. Supe por otro criollo que esos rusos buscaban un lugar y alguien había extraviado los papeles, pero ellos se largaron igual y caminaban junto al tren. Iban calladitos, como en misa, las mujeres, los hombres, los viejos, detrás del hombre que leía su Libro. Y de pronto, como en la procesión, cantaban y murmuraban en su lengua los rezos a ese Dios (el suyo o del de ellos, don) que les había prometido un poco de paz en esta tierra. (...) Pero [yo le hablaba los rusos] de esos pobres cristianos que caminaban junto a las vías del tren. Como le decía: a veces los pasajeros les tiraban un pan o las sobras de las comidas y ellos se alimentaban de eso y también de los yuyos y del pasto lo mismo que los animales. Así fue, nomás. (...) No terminé el cuento todavía. Al final, los rusos llegaron a su campo. Sembraron, tuvieron hijos. Lo de siempre. Pero uno, fíjese lo que son las cosas, se hizo más gaucho que los otros. Hombre de a caballo, buen arriero. A él lo conocí bien. (...) Ese mozo bien entrazado, con rastra de plata y cuchillo en la cintura, era uno de los judíos que caminaban junto al tren (...) y hablaba en criollo como usté y como yo. ${ }^{3}$

\footnotetext{
${ }^{3}$ ORGAMBIDE, 1984, p. 35-37. Como se trata de uma análise de textos literários escritos em espanhol, para os leitores em português, vai ser apresentada uma proposta de tradução que tem acompanhado o processo de pesquisa em andamento. O procedimento de proposição da tradução do trecho analisado será mantido ao longo desta reflexão, para todos os textos de outras línguas. Tradução: "Eu o vi, senhor; vi aqueles infelizes andando junto aos trilhos do trem, mendigando um pedaço de pão. Eu juro. Eles estavam indo para Entre Rios, para campos que ninguém sabia como explicar. Mas isso, você não vai acreditar, seguiam andando atrás de um velho que cantava e lia o Livro dele e falava de Deus. (...) Eu os vi caminhando, como eu digo, por dias e dias pelo campo. Não pude ajudá-los, não muito, porque também andava perseguido. Não, eles não eram perseguidos pela partida. Mas pela desgraça, nada mais. Soube de outro criollo que esses russos estavam procurando um lugar e alguém tinha extraviado os papéis, mas eles partiram do mesmo jeito e caminhavam junto ao trem. As mulheres, os homens, os idosos iam silenciosamente, como em missa, atrás do homem que lia o livro. E de repente, como em uma procissão, eles cantavam e murmuravam em sua língua as orações a esse Deus (o seu ou o deles, sinhô) que lhes havia prometido um pouco de paz nesta terra. (...) Mas [depois de uma digressão, ele retoma: estava falando] sobre os russos, sobre aqueles cristãos pobres que andavam nos trilhos do trem. Como eu disse: às vezes os passageiros jogavam pão ou sobras de suas refeições e se alimentavam dele e também das ervas daninhas, do pasto mesmo, como os animais. Assim foi, simplesmente assim. (...) Ainda não terminei a história. No final, os russos chegaram ao seu campo. Eles semearam, tiveram filhos. O de sempre. Mas um, observe como são as coisas, tornou-se mais gaucho que os outros. Homem a cavalo, um bom peão. Esse eu conheci bem. Aquele moço bem arrumado, com uma rastra de prata e uma faca na cintura, era um dos judeus que caminhava junto ao trem (...) e falava em criollo, como o sinhô e como eu."
} 
O caminho percorrido pelo campo, dias a fio, ao longo da linha do trem, indica outra imprecisão, como se esse grupo, guiado por um líder espiritual, à maneira de um Moisés dos pampas, caminhasse a esmo, sem rumo, em busca daquele pedaço de terra que ninguém conseguia localizar ou precisar onde ficava. Desse grupo que conseguiu se fixar à terra, um dos homens tornou-se mais gaucho do que os demais e esse gaucho judio, temido, descrito incorporou elementos gauchos, a fala criolla inclusive. Isso também acontece com o senhor Burtfichtz, que aprendeu a lidar com o solo, com as máquinas agrícolas e com o espanhol. Tem-se aí, no processo de ocupação dos campos pelos imigrantes judeus, a mistura com os nativos; tem-se o agaucharse dos judeus, tal qual a construção celebrativa de Gerchunoff.

A imigração judaica, a ida ao campo, a descrição da paisagem, as passagens mais explícitas referentes aos gauchos judios de Hacer la América evidenciam um parentesco, reivindicando como uma de suas precursoras a obra Los gauchos judios, de Alberto Gerchunoff.

La tarde se extingue en la dulzura de una paz beatífica. El cielo se ha teñido de fulgores amarillos del sol. Los animales, conocedores de la hora, van aproximándose del corral. La colonia se recoge en el descanso. Tras de los ranchos, los arados levantan sus brazos en forma de lira y, cerca del arroyo, el cencerro de la yegua repica. ${ }^{4}$

Neste trecho de Gerchunoff lemos que no pampa está a liberdade entoada do hino argentino, está a liberdade da sobrevivência, mas também está um certo tom de desamparo, de solidão, que estão presentes nessa obra de Orgambide ou, ainda, nas reflexões, geralmente em tom de diálogo com o sogro, a respeito de suas questões sobre a religião, sobre o tempo. Podemos notar, no trecho a seguir que ainda que a pátria tenha ficado distante, percebe-se um tom de otimismo de uso do corpo no trabalho na terra.

La locura del mundo, Israel, la que nos dejó sin patria, esa locura que envilece al pensamiento, oh Dios, el orgullo y la maldición de nuestra raza. (...) Mi Liuba quiere ser esto o aquello: artista o católica o argentina ¿quién soy yo para llamarla renegada? Lo sé, lo sé: nos debemos a nuestras tradiciones y no las vamos a abandonar. ¿Pero acaso ella es culpable de esa locura de siglos que nos condena y nos humilla y nos envilece, Israel? ¿Qué han hecho de nosotros? (...) Estoy cansado, muy cansado Israel. Hoy trabajé en la cosecha a la par de los jóvenes. Por un momento (sólo un instante) volví a sentir es alegría del cuerpo que no se

\footnotetext{
${ }^{4}$ GERCHUNOFF, 2007, p.35-37. Tradução: “A tarde se extingue na doçura de uma paz beatífica. O céu foi tingido com brilhos amarelos do sol. Os animais, conhecedores da hora, estão se aproximando do curral. A colônia se recolhe no descanso. Atrás dos ranchos, os arados erguem os braços em forma de lira e, perto do riacho, o sino da égua toca."
} 
necesita pensar, que se mueve o funciona como una máquina perfecta. Pero uno no elige ser joven como no elige ser judío. Uno es lo que es. ${ }^{5}$

Há um de distanciamento desse mito, da composição dessa figura na novela, El arresto, de Perla Suez. Antes de nos atermos a ela, no entanto, é importante ressaltar que nas outras novelas que compõem a Trilogía de Entre Ríos - Letargo e Complot - esse distanciamento também é evidente.

Em Letargo, temos uma narradora que volta às terras da infância, por caminhos tortuosos, passando por memórias de violência familiar, a morte do irmão, a doença da mãe, em um ambiente externo hostil, com a presença próxima das tempestades, dos dias cinzentos e, quando estamos diante da paisagem, ela é mais ríspida e lembra uma aura de violência que ronda, violência essa que é tanto individual quanto familiar e, ainda, pode remeter a uma experiência coletiva. Em Complot esse distanciamento se dá de forma evidente desde a epígrafe que recorre a uma citação indireta de Martínez Estrada: "En el origen de la tragedia argentina hay una gota de sangre y una de semen, producto de la violación fundante". ${ }^{6}$ Resta nela, já anunciada uma violência fundante dessa região, não apenas direcionada para o grupo de imigrantes judeus. Nessa última novela, a sensação de proximidade com a violência também acompanha o passar das páginas, o ataque espreita e essa violência por vezes é sutil, por vezes, escancarada. Não há paz possível em um ambiente como esse, não há qualquer idealização do trabalho no campo ou de sua paisagem hostil. Essa barbárie pode ser lida à luz da proposta de Sarmiento ${ }^{7}$ mas, no entanto, para os narradores de Suez, a barbárie não está restrita ao campo. Em El arresto, lemos:

\footnotetext{
${ }^{5}$ ORGAMBIDE, 1984, p. 129. Tradução: "A loucura do mundo, Israel, a que nos deixou sem pátria, essa loucura que degrada o pensamento, oh Deus, o orgulho e a maldição de nossa raça. (...) Minha Liuba quer ser isso ou aquilo: artista ou católica ou argentina, quem sou eu para chamá-la de renegada? Eu sei, eu sei: devemos às nossas tradições e não vamos abandoná-las. Mas por acaso ela é culpada daquela loucura secular que nos condena, humilha e nos degrada, Israel? O que fizeram de nós? (...) Estou cansado, muito cansado, Israel. Hoje, trabalhei na colheita lado a lado com os jovens. Por um momento (apenas um instante) senti novamente a alegria do corpo que não precisa pensar, que se move ou funciona como uma máquina perfeita. Mas não escolhe ser jovem, como não se escolhe ser judeu. Você é o que é." ${ }^{6}$ Ezequiel Martínez Estrada, citado por Luis Frontera (apud SUEZ, 2006, p. 187). É assim a epígrafe, como se ela mesma manifestasse sua violação ao clássico sem citá-lo diretamente. Tradução: "Na origem da tragédia argentina tem uma gota de sangue e uma de sêmen, produto da violação fundante."

${ }^{7}$ Trata-se da obra Facundo o civilización y barbárie que propõe desde seu título um dualismo que marca as tensões entre cidade e pampa (universo rural), entre unitarismo (liberais que prezavam pela unificação, centralizando o poder em Buenos Aires, no processo de disputa do projeto nacional pós-independência que acarretou em uma guerra civil) e federalismo (coalizão de caudilhos que favoreciam a autonomia das províncias), entre ilustração (educação) e "incultura", entre o processo de olhar para fora (visando uma internacionalização) e o seu oposto (olhar para as províncias e para os resquícios coloniais), entre o branco (que vestia à moda europeia) e as outras etnias (trajadas de forma típica). Outra forma de marcar esse dualismo é pensando na localização e definição do "eu" e do "outro", sendo feito, para o primeiro, um esforço legitimador e, para o segundo, uma ação para denegri-lo. Todas essas antíteses
} 
A Ushuaia me quieren mandar. El destierro puede durar toda la vida. (...) Anoche me sometieron a lo que llaman examen de consciencia. (...)

La historia que aprendí en la escuela decía que la barbarie está en el campo y la civilización en la ciudad. Lo que sucedió esta semana aquí, me hace ver a Buenos Aires como un mar de barbarie, una gran ciudad donde se ven costumbres perversas y se escucha un irritante murmullo que hace que uno se transforme en un extraño en su propio país. Quiero que sepa que no voy a corroborar una culpa que no tengo. ${ }^{8}$

Serão aprofundadas as discussões sobre essa novela mas pode-se perceber que a violência e a barbárie estão também na cidade, região na qual deveriam reinar os preceitos da civilização. Nessa passagem, Lucien que está preso indevidamente sofre e busca um diálogo com o pai distante.

Pode ser possível, no entanto, a partir destas novelas de Suez, propor uma aproximação a Gerchunoff, desde que a partir do foco nas experiências rurais, no campo, com narrativas que voltam as costas ao rio da Prata, à cidade de Buenos Aires. Em Orgambide, nesse quesito, se distanciaria, já o trecho a respeito dessa região é curto e pouco explorado se comparado à narração do desenvolvimento da vida dos imigrantes que aportaram na Argentina para "fazer a América" que ficaram na cidade.

Seguimos, então, com El arresto e a narração de uma história familiar de pessoas que vivem dos campos de arroz e que sentem a dureza do clima e do trabalho: lemos sobre a dificuldade no trato da terra, as perdas na produção agrícola por conta de problemas climáticos ou de peste, sobre mortes: a da matriarca no parto de Lucien e a do primogênito, Max, ao ser atingido por um raio. Na leitura, deflagra-se, mais uma vez, a força e a fúria da natureza da região. Não há qualquer

apresentadas são indissociáveis, são dois mundos que convivem conflituosamente, expressos inclusive no título original com o aditivo "y" (ou "e", na tradução em português), afirmando, assim, que se trata de termos irredutíveis. Sarmiento, portanto, ao buscar a síntese da "civilização", do progresso, aos moldes europeus, pensa também em uma originalidade local, dada as condições geográficas que, segundo ele, condicionavam o caráter dos homens, se dispõe a inventar essa Argentina, a apresentar sua história rumo ao progresso social ao qual, euforicamente, chega em seus dois últimos capítulos quando, por meio de realidades possíveis, a civilização vencerá o horror e a barbárie representados pelo ditador Juan Manuel Rosas. Sarmiento propõe que é papel dos intelectuais e políticos levar a nação a essa "civilização", sendo a educação e o branqueamento - possibilitado pela imigração europeia - as chaves para essa construção da cidadania e da nacionalidade, mas tratava-se um uma imigração europeia específica, anglo-saxã.

${ }^{8}$ SUEZ, 2006, p. 159. Tradução: "Querem me mandar para Ushuaia. O desterro pode durar toda a vida. (...) À noite fui submetido ao que eles chamam de exame de consciência. (...) / A história que aprendi na escola dizia que a barbárie está no campo e a civilização na cidade. O que aconteceu nesta semana aqui me fez ver Buenos Aires como um mar de barbárie, uma grande cidade onde se vê costumes perversos e se ouve um murmúrio irritante que faz você se tornar um estranho em seu próprio país. Quero que saiba que não corroborarei uma culpa que não tenho." 
idealização do trabalho do campo, ou ainda, não faz parte das descrições passagens que enaltecem as paisagens bucólicas, ao contrário do proposto por Gerchunoff e reinvindicado por Orgambide.

Vuelvo a verlo a usted padre, absorto, refugiado en el silencio, caminando despacio por el borde del canal. La cosecha está perdida, dice. El sol se ha escondido, la arrocera está fangosa, huele a vómito. No hay viento. La tarde cae apacible. Escucho el graznido de una tijereta que cruza el aire y hay moscardones azul eléctrico que zumban por todos los lados. Veo la negritud del cielo a lo lejos, escucho a los perros que lloran, y a usted, padre, que murmura, y qué puedo hacer yo...

O trabalho no campo foi perdido. Na descrição, a plantação de arroz está perdida, lamacenta, cheira mal e está repleta de insetos. Nada disso revela uma idealização do trabalho no campo. Enquanto em Gerchunoff, é no trabalho na terra que está a salvação, quando narra, por exemplo, a história de Guedalí:

(...) cuando la servidumbre quedó abolida, fue despojado de sus tierras, y su fortuna sufrió todavía más hondos quebrantos con la guerra emprendida por Alejandro II. Rico aún, continuó viviendo en la ciudad que había fundado hasta oír noticias de América. (...) Y vino con las primeras inmigraciones a Entre Ríos. En Entre Ríos completó el ideal de su existencia que fue siempre labrar la tierra y comer pan de su trigo y legumbres de su huerta. ${ }^{10}$

Ou, ainda, em Orgambide, em que o trabalho no campo satisfaz e é idealizado:

Ya no soy joven, Israel, lo sabes, al menos no tan joven como desearía. El trabajo en el campo me cansa bastante, pero es un cansancio bueno, que me permite dormir sin zozobras, sin esos extraños sueños (...), sueños donde lo evidente se exaspera, hasta transformarse en otra forma (ambigua y misteriosa) de realidad. Estoy aprendiendo a manejar la trilladora, una máquina muy bella, un carro altísimo de fierro que me lleva por estos campos en los que Dios ha sido generoso:

\footnotetext{
${ }^{9}$ SUEZ, 2006, p. 114. Tradução: "Volto a vê-lo, pai, absorto, refugiado no silêncio, caminhando lentamente pela beira do canal. A colheita está perdida, diz. O sol se escondeu, o arrozal está lamacento, cheira a vômito. Não há vento. A tarde cai calma. Ouço o barulho de uma cigarra que atravessa o ar e há varejeiras azul elétrico zumbindo por todos os lados. Vejo a escuridão do céu à distância, ouço os cães que choram, e ao senhor, pai, que murmura, e o que eu posso fazer..."

${ }^{10}$ GERCHUNOFF, 2007, p. 153. Tradução: "quando a servidão foi abolida, ele foi despojado de suas terras e sua fortuna sofreu perdas ainda mais profundas com a guerra travada por Alexandre II. Ainda rico, ele continuou morando na cidade que havia fundado até ouvir notícias da América. (...) E veio com as primeiras imigrações para Entre Ríos. Em Entre Ríos, ele completou o ideal de sua existência, que era sempre trabalhar a terra e comer pão de seu trigo e legumes de sua horta."
} 
pura tierra negra, Israel. Liuba trabaja en la cosecha y continúa con su costumbre de ser feliz. ${ }^{11}$

\section{Aproximações}

São, talvez, mais amplas as áreas de contato que de certa forma aproximam essas obras. Por um lado, temos a questão da hibridização da forma, por outro, temos a presença das relações entre o tom memorialístico relacionado às ascendências judaicas ou a uma certa familiaridade com a religião que tangem a memória, a estrangereidade e o esquecimento, temos a ida à cidade e a também as marcas de violência que esse grupo de imigrantes vai sofrer. Ou ainda, trata-se de obras que narram traumas coletivos, como o da coletividade judaica, mas que apresentam traços de traumas individuais que podem remeter a certas experiências biográficas de cada um de seus autores. Em Pedro Orgambide, além do histórico familiar de imigração e da ascendência judaica, tem-se a experiência do exílio e do próprio autor ser obrigado a emigrar. Já em Perla Suez, tem-se a infância nas colônias, além da ascendência judaica.

Sobre uma certa hibridização da forma, um rápido comentário. Em ambas são utilizados elementos distintos para incrementar a trama. Em Hacer la América, temos trechos de sainetes, representação de cartazes, um trecho de um roteiro cinematográfico. Já em El arresto, temos a reprodução de uma página do Sidur em caracteres hebraicos e a "reprodução" do documento datilografado da prisão de Lucien, do arquivo policial. Seguiremos a discussão elencando a reflexão separadamente, por obra.

Em Hacer la América, há a inserção de um universo imaginário traçado pelos fios da memória, que transita pela questão do exílio, da errância, fazendo uso da permanência da “estrangeria”, em outras palavras, da presença contínua do sentimento de ser estrangeiro, de não pertencer a lugar nenhum. E o desenvolvimento dessas questões, em Orgambide, centrada na figura do judeu errante, já está em sua obra pregressa, Las aventuras de Edmund Ziller (1976), que

\footnotetext{
${ }^{11}$ ORGAMBIDE, 1984, p.42. Tradução: "Não sou mais jovem, Israel, pelo menos, não sou tão jovem quanto eu gostaria. Trabalhar no campo me cansa muito, mas é um bom cansaço, que me permite dormir sem ansiedade, sem aqueles sonhos estranhos (...), sonhos onde o óbvio é exasperado, até transformar-se em outra forma (ambígua e misteriosa) de realidade. Estou aprendendo a operar a máquina de debulhar, uma máquina muito bonita, um carro de ferro altíssimo que me leva a esses campos em que Deus foi generoso: pura terra negra, Israel. Liuba trabalha na colheita e continua seu hábito de ser feliz."
} 
representa, no limite, esse homem judeu que se desloca pelo espaço e pelo tempo, sem se fixar em nenhum momento do trajeto. Voltando-se ao romance Hacer la América, temos:

En cada atardecer, cambia la marea de los símbolos. Desde la borda del barco, David Burtfichtz admite esa verdad tan simple que barruntaran los navegantes del océano y Heráclito y su paisano Yurkovsky y cada uno de los pasajeros que, con el transcurrir de los días, se acercan a un porvenir, a una patria, quizá (...) y piensa que la marea de los símbolos puede ser favorable ¿por qué no? que la esperanza es una probabilidad como cualquier otra, una forma de sobrevivir y adelantar el presente, el origen de los entusiasmos, se ríe David Burtfichtz. ${ }^{12}$

Neste trecho, identificamos uma marca de esperança como resultado dessa imigração [dessa fuga], frente aos pogroms, ${ }^{13}$ ao brutal assassinato do sogro em uma sinagoga. A partir da leitura dessa passagem não é possível não se desviar para se aproximar ao seu escritor, judeu, à margem de sua pátria, forçado por uma ditadura a viver no exílio. Essa não seria uma forma de explorar essas vivências entre a tradição judaica - e as questões sobre as quais esse personagem conversa com seu falecido sogro - e a imigração forçada? David Burtfichtz, portanto, representa o judeu errante, assim como o autor, filho de imigrantes judeus que, por sua vez, também teve que deixar sua terra natal:

¿Te quieres ir? ¿A América dices? ¿Quiere llevarte a mi Raquel y a mi Liuba? ¿Crees que allí encontrarás la paz? No hay paz para nosotros, David. Puedes escapar de los cosacos, puedes ocultarte en el fin del mundo, pero también allí encontrarás la maldad, el odio a nuestra gente. ¿No? ¿Qué sabes tú de América, David? Has leído algunos libros, tienes, como se dice, una buena educación. ¿Pero sabes, David? Eres un judío, un leproso al que hay que tener alejado, siempre serás distinto a los demás. ${ }^{14}$

\footnotetext{
${ }^{12}$ ORGAMBIDE, 1984, p.30. Tradução: “A cada entardecer, a maré de símbolos muda. Do guarda mancebo do navio, David Burtfichtz admite essa simples verdade de que conjecturaram os navegantes do oceano e Heráclito e seu compatriota Yurkovsky e cada um dos passageiros que, com o transcorrer dos dias, se aproximam de um futuro, uma pátria, talvez (...) e pensa que a maré de símbolos pode ser favorável, por que não? a esperança é uma possibilidade como outra qualquer, uma maneira de sobreviver e avançar no presente, a origem dos entusiasmos, ri David Burtfichtz."

${ }^{13}$ São os massacres contra judeus organizados no processo de russificação do império tzarista, no final do século XIX. ${ }^{14}$ ORGAMBIDE, 1984, p.17. Tradução: "Quer ir? América, você diz? Você quer levar minha Rachel e minha Liuba? Você acha que lá você encontrará a paz? Não há paz para nós, David. Você pode escapar dos cossacos, você pode se esconder no fim do mundo, mas lá você também vai encontrar mal, ódio pelo nosso povo. Não acha? E o que você sabe sobre a América, David? Você leu alguns livros, você tem, como dizem, uma boa educação. Mas você sabe, David? Você é um judeu, um leproso que deve ser mantido longe; você sempre será diferente dos outros."
} 
A existência de uma tensão já está explicita, mas há uma possibilidade de esperança proporcionada pela imigração:

Desde el ojo de buey, América es ese río ancho como el mar y las lavanderas negras que cantan en la orilla mientras lavan la ropa de los ricos. América son los veleros y los barriles y las estibas de los muelles, un olor a pescado y a brea, los barcos de vapor, la torre de una iglesia que parece emerger de las aguas; es un olor de almizcle, de bolsas de maíz, de sogas, de navegaciones, olor de bodegas, sabor de ron y caña y aguardiente holandesa, voces de hombres bronceados por el sol, envilecidos por los puertos, un sabor salado de mar que se mezcla en el río que se abre en un enorme estuario. Desde el ojo de buey o desde el ojo de Liuba, América son los trigales de los que habla el barón de Hirsh a los judíos pobres de la Europa Oriental (...). ${ }^{15}$

David Burtfichtz contempla, do navio, a aproximação da Argentina, tendo seguido o chamado do Barão Moritz von Hirsh auf Gereuth, ou simplesmente Barão Hirsh, que fundou a Jewish Colonization Association (JCA), em 1891, que organizava colônias agrícolas nas Américas, sendo a primeira na província de Santa Fe, chamada Moisesville. ${ }^{16}$ Mesmo sem qualquer experiência na agricultura, esta personagem [assim como muitos judeus não-ficcionais] pega um trem em Buenos Aires, com sua família, e ruma para Entre Rios. Haverá esperanças para estes que buscam sobreviver à perseguição racial e religiosa, seguindo identificando-se com a tradição judaica em uma cooperativa agrícola no litoral argentino?

O projeto de construção de uma nacionalidade argentina "fue definiéndose en términos de singularidad cultural, arrastró tras de sí otra definición de la sociedad nacional, caracterizada por la diferencia y la exclusión de lo distinto". ${ }^{17}$ Um dos grupos excluídos, portanto, dessa identidade, estereotipado e apontado como diferente, é o dos judeus. Assim, se num primeiro momento, para a família imigrante [imaginada] havia uma certa esperança ao chegarem ao porto de Buenos Aires,

\footnotetext{
15 ORGAMBIDE, 1984, p. 09-10. Tradução: “Da vigia, a América é esse rio tão largo quanto o mar e as lavadeiras negras que cantam nas margens enquanto lavam as roupas dos ricos. A América é os veleiros, os barris e os paletes das docas, um cheiro de peixe e alcatrão, os barcos a vapor, a torre de uma igreja que parece emergir das águas; é o cheiro de almíscar, de sacos de milho, de cabos, de navegações, o cheiro de porões, o gosto de rum e cana e aguardente holandesa, as vozes de homens bronzeados pelo sol, envelhecidos pelos portos, um sabor salgado do mar que se mistura com o rio que se abre em um enorme estuário. Da vigia ou dos olhos de Liuba, a América é os campos de trigo dos quais o barão de Hirsh fala aos judeus pobres da Europa Oriental (...)."

${ }^{16}$ Segundo Javier Sinay (2013, p.43), o Barão seguiu com esse empreendimento como forma de dar vazão a sua herança. Maurice (nome afrancesado do Barão) havia acumulado fortuna mas perdido seus dois filhos, a primeira um pouco antes de nascer e o segundo com menos de trinta anos por conta de uma pneumonia. Como, então, com toda essa fortuna, garantir a descendência? Foi daí que surgiu o impulso de criação dessa organização sem fins lucrativos que garantiria a sobrevivência de famílias judaicas da violência.
}

${ }^{17}$ BERTONI, 2001, p. 77. 
na certeza de que, ao contrário da maioria dos imigrantes de outras nacionalidades, estes não teriam para onde voltar, num segundo momento, conforme vamos, como leitores, nos aproximando de segunda década do século XX, acompanhamos a sistematização e o incremento da violência , com a perseguição aos judeus.

Por conta dos desejos da filha, os Burtfichtz mudam-se para Buenos Aires, para o bairro judeu. David, que ao final do romance vai ter o mesmo destino que o sogro [brutalmente assassinado], passa a trabalhar em uma papelaria e lá verá pintado no muro manifestações explícitas de ódio, de intolerância religiosa: "HAGA PATRIA. MATE A UN JUDIO", 18 por obra de jovens que estavam de carro e que, ainda, ao terminarem o feito, atiram com uma arma ao alto. Havendo, portanto, uma circularidade na narrativa, cumprindo-se as previsões sombrias do sogro que pergunta ao genro antes da imigração: “CCrees que allí encontrarás la paz? No hay paz para nosotros, David.". 19

Essa maldade e esse ódio aparecem em diversas passagens do romance e estão igualmente presentes na história argentina, em que houve perseguições à comunidade judaica. Como afirma Finchelstein, "Fue durante la llamada Semana Trágica de 1919 cuando el antisemitismo argentino transcendió los escritos y se convirtió en práctica victimizadora. Luego fue con los fascistas de en las décadas del 30 y 40 que el nacionalismo antisemita ocupó un lugar principal”. ${ }^{20}$ A questão do antissemitismo durante a Semana Trágica será retomada na discussão sobre a novela de Perla Suez.

Essa violência está expressa em algumas passagens no romance mais evidentes e recorrentes ao final da narrativa, quando estamos em 1919, e a filha de David é violentada e ele vai defendê-la e acaba deixado no empedrado de sua loja, pedindo para que a filha lhe cante uma cantiga antiga...

Esa tarde, un grupo de muchachos enmascarados entró en la librería del señor Burtfichtz.

- ¡Arriba las manos, judío!

- ¡Vamos a quemarlos a todos!

- Esperamos demasiado tiempo.

- ¿Qué día es hoy?

$-\ldots$

- ¡No lo sabe, no lo sabe! - se burló el enmascarado de la voz infantil- ¡Pida perdón, Herodes!

$-\ldots$

${ }^{18}$ ORGAMBIDE, 1984, p. 173. Trecho originalmente grafado em caixa alta. Tradução: “FAÇA A PÁTRIA. MATE UM JUDEU".

${ }^{19}$ ORGAMBIDE, 1984, p. 17. Tradução: "Você acredita que encontrará a paz lá? Não há paz para nós, David"

${ }^{20}$ FINCHELSTEIN, 2012 (ebook), Loc. 732. 
- Está cagando de miedo, Déjenlo.

$-\ldots$

- ¿En qué año vivimos, judío?

- 1933 - respondió en alemán el señor Burtfichtz aunque desconocía aquel idioma.

- ¿No ven? Ellos viven en cualquier país, en cualquier tiempo. Todo les da lo mismo. $^{21}$

1933 irrompe na narrativa e aponta para o ano em que a perseguição aos judeus passou a fazer parte do programa de governo da Alemanha nazista. Se nesse momento ainda a perspectiva de genocídio não era clara, as intenções já estavam postas, principalmente com o desenvolvimento, desde fins do século XIX, da construção de uma alteridade negativa e, com isso:

La figura del judío pudo dar cuenta de muchas de estas necesidades: construida y/reforzada por la Iglesia cristiana medieval, fue seleccionada con facilidad como la imagen prototípica del "otro no normatizado" y por lo tanto, como la que representará, en nivel más exagerado y estereotípico, a los miembros de 'la otra' especie. $^{22}$

Cabendo aqui a lembrança, inclusive, do que escreveu Primo Levi no prefácio de sua obra $E$ isto um homem?: "Muitos, pessoas ou povos, podem chegar a pensar, conscientemente ou não, que 'cada estrangeiro é um inimigo", 23

A partir desses elementos discutidos na obra de Orgambide, passamos a de Suez. Temos, então, como foco, a novela El arresto, a partir da qual é traçada uma proposta de leitura que visa refletir sobre certos traços da presença da condição judaica no que tange a memória, o esquecimento, a estrangereidade e, ainda, a ida à cidade desses judeus das colônias e a também as marcas contínuas de violência que acompanham esse grupo de imigrante e seus descendentes.

"Noé dijo que mamá permanecía doblada sobre la batea, dando jabón a la ropa, y que después se secaba las manos sobre el delantal que llevaba puesto y se ponía a leer unas hojas que tenía escritas. Noé dijo también que, un día, aquellas hojas

\footnotetext{
${ }^{21}$ ORGAMBIDE, 1984, p. 290. Tradução: "Naquela tarde, um grupo de meninos mascarados entrou na livraria do senhor Burtfichtz. / - Mãos ao alto, judeu! / - Vamos queimar todos eles! / - Esperamos muito tempo. / - Que dia é hoje? / - .. / - Você não sabe, você não sabe! - zombou o mascarado de voz infantil - Peça perdão, Herodes! / -... / Ele está cagando de medo, deixe-o. / - ... / - Em que ano vivemos, judeu? / - 1933 - O senhor Burtfichtz respondeu em alemão, embora não conhecesse esse idioma. / - Não vem? Eles moram em qualquer país, em qualquer tempo. Tudo, para eles, dá no mesmo."

${ }^{22}$ FEIERSTEIN, Daniel, 2014, p. 217-218.

${ }^{23}$ LEVI, 1988, p. 07.
} 
volaron como tijeretas y lo siguieron a uste con otros pájaros, por detrás del arado que usted conducía." 24

Lucien dialoga constantemente com o pai a quem remete essas suas lembranças. Nessa citada, está a figura da mãe, que não chegou a conhecer, que faleceu de eclampsia no pós-parto, a partir de histórias que ouvia do irmão Nóe. Essa pretensão de estabelecimento de um diálogo com uma figura ausente, também está, como vimos, em Orgambide, em cuja obra temos o diálogo unilateral entre David e seu falecido sogro, Israel.

Estão expressas no texto as marcas da violência, do trauma e de como essas passagens ficam gravadas na memória:

"No voy a olvidar mientras viva su mano en alto esgrimiendo un fusil. Me sacó el reloj de oro que había sido de Max y el dinero y todo lo que tenía en los bolsillos. Uno de los policías me pegó una trompada en el estómago. Yo tenía la boca amarga y la cabeza vacía. Me faltó fuerza para decir una sola palabra.

Padre, me miraba como usted decía que lo miraban a usted, cuando llegó a Buenos Aires.

No nací en una buena época. Tengo que resistir, aunque mi vida siga siendo dura y angustiosa. Estoy como si hubiese hecho un largo viaje a caballo desde que nací. Buenos Aires no me va obligar a renunciar a mi decencia. (...)"25

Neste trecho, fica latente a impossibilidade do esquecimento e a presença do trauma, de um trauma coletivo e que atravessa gerações, com a sensação de não pertencimento, de não aceitação dos outros que formam um coletivo.

Ao se lembrar, Lucien percebe aquilo que foi silenciado e esquecido em outro momento, também se direcionado ao pai, que era o portador da palavra, da tradição: "Vasili, usted dijo que estuvo toda la noche contemplando la lluvia que caía y dijo haberse levantado de la ruina más de una vez. Pero había muchas cosas que usted no dijo..." ${ }^{26}$ Nessas reticências cabem perguntas que

\footnotetext{
${ }^{24}$ SUEZ, 2006, p. 132. Tradução: "'Noé disse que a mamãe continuava curvada sobre a calha, dando sabão às roupas, e depois secava as mãos no avental que usava e começava a ler algumas folhas que tinham escritas. Noé disse também que um dia essas folhas voaram como tesourinhas e que o seguiram com outros pássaros, atrás do arado que o senhor estava dirigindo."

${ }^{25}$ SUEZ, 2006, p. 151. Tradução: "Não vou me esquecer enquanto viver de sua mão levantada segurando um rifle. arrancou o relógio de ouro que pertencia a Max e o dinheiro e tudo o que tinha nos bolsos. Um dos policiais me deu um soco no estômago. Eu tinha a boca amarga e a cabeça vazia. Faltou forças para dizer uma única palavra. / Pai, ele me olhava como o senhor dizia que olhavam, quando o senhor chegou em Buenos Aires. / Não nasci em uma boa época. Tenho que resistir, embora minha vida siga sendo difícil e angustiante. Estou como se estivesse em uma longa viagem a cavalo desde que nasci. Buenos Aires não vai me obrigar a desistir de minha decência."

${ }^{26}$ SUEZ, 2006, p. 113. Tradução: "O senhor disse que passou a noite inteira contemplando a chuva que caía e disse que havia se levantado da ruína mais de uma vez. Mas havia muitas coisas que o senhor não disse..."
} 
poderiam ser feitas ao pai para a superação do trauma, para que fosse possível levantar da ruína mais uma vez. O filho está desiludido e em seu diálogo imaginado segue com seu questionamento em relação ao pai, às memórias contadas, à visão do mundo idealizada e ao processo de integração a uma comunidade, Lucien diz: "Usted dice que no hay otra tierra generosa como ésta. ¿Por qué idealiza todo, padre? Tal vez sea porque usted dejó de ser consciente del suelo que pisan sus pies. Se olvida que aún somos habitantes de este país; apenas si somos sus ocupantes..."27 Nessa passagem, lê-se o sentimento de não pertencimento, de um lugar à margem, de uma perspectiva distinta da paterna.

Como já foi discutido, parte do que foi o processo de imigração, formação das colônias judaicas no interior e o processo de agaucharse dos imigrantes, judeus, apresenta-se aqui o impacto desse processo de imigração na cidade de Buenos Aires: “A chegada dessa multidão de estrangeiros em Buenos Aires (...) além de tornar a cidade desumana, comprometeu a identidade nacional e modificou a mentalidade do povo argentino." 28 Estamos falando da passagem do século XIX para o XX, período no qual a população aumentou consideravelmente e essa avalanche imigratória “permitiu que a população argentina, normalmente pequena e dispersa, quadruplicasse entre 1869 e 1914: dos cerca de 1,8 milhão de habitantes contados em 1869, saltou-se a mais de 3 milhões em 1890 e a quase 8 milhões na metade dos anos dez do século XX”. ${ }^{29}$

No romance de Orgambide, as imigrações são centrais, como é possível perceber pelo título: Hacer la América que expressa, em si, as ressonâncias desta expressão que é também um "lugar común y [un] sueño incumplido"30 desses imigrantes que chegaram na Argentina para "fazer a América", em um intervalo de tempo que vai de fins do século XIX até as primeiras décadas do XX, que coincide com o tempo da novela de Suez. Nesse momento, em que recebeu esse enorme contingente de imigrantes, a Argentina encontrava-se, segundo Lilia Ana Bertoni, "en medio de un proceso inconcluso de formación de la nación, entendido también en el sentido de constitución de una sociedad nacional". ${ }^{31}$ Existiam diferentes projetos patrióticos, diferentes sociedades argentinas em potencial a serem desenvolvidas, com concepções distintas sobre o que deveria ser essa nação.

\footnotetext{
${ }^{27}$ SUEZ, 2006, p. 129. Tradução: “O senhor diz que não há outra terra generosa como esta. Por que idealiza tudo, pai? Talvez seja porque o senhor deixou de estar consciente do chão em que seus pés pisam. Esquece-se que ainda somos habitantes deste país, apenas, sim, somos seus ocupantes..."

${ }^{28}$ CAPELATO, 2009, p. 72.

${ }^{29}$ PINTO, 1998, p. 50.

${ }^{30}$ ORGAMBIDE, 1981, p. 103. Tradução: "lugar comum e [um] sonho incompleto"

${ }^{31}$ BERTONI, 2001. p. 11.
} 
Sugerindo polos opostos: um projeto seria o de uma Argentina aberta, tolerante e integradora - a dos cosmopolitas que defendiam a constituição liberal e as leis de cidadania, aceitando que o processo de naturalização do estrangeiro deveria ser feito de forma voluntária, garantindo amplas liberdades e aceitando suas atividades econômicas e culturais, apostando na diversidade; o outro projeto, mais fechado, exclusivista - uma Argentina dos nacionalistas que pregavam a necessidade da homogeneização cultural: língua, raça, cultura através do passado histórico, para a existência de uma nação livre da contaminação estrangeira. E entre ambos havia conflitos, tensões e distensões. E, segundo a autora, vale lembrar que na Argentina,

los inmigrantes no sólo eran mano de obra vital para una economía en expansión, extranjeros que deberían incorporarse a una sociedad con diferentes grados de integración y conflicto, potenciales ciudadanos de un sistema político en gestación e integrantes de una nación que estaba formándose, sino, además, y al mismo tiempo, eran miembros de otras naciones distintas, también en formación. ${ }^{32}$

Com isso, retomamos a novela de Suez, acompanhando a chegada de Lucien à cidade de Buenos Aires: "Era domingo y Lucien caminó un rato por el puerto. Contempló un barco de pasajeros con bandera italiana que estaba amarrado a una de las dársenas." 33 Além dessa menção indireta mas que marca uma presença visível e constante da chegada de imigrantes no período, Lucien começa a trabalhar como oficinista en el ferrocarril, ingressa na Faculdade de Medicina e lá faz amizade com Luigi Melle:

que trabajaba en el matadero. [Y que] Habló de su patrón, como si Lucien lo conociera.

Dijo que yo era un piojoso italiano y que no iba a pagarme ni un centavo.

Luigi Melle, los ojos fijos en la cara de Lucien, aclaró,

¡Dio cane...! Si yo soy un piojoso italiano, él no es más que un mísero holandés. ${ }^{34}$

\footnotetext{
${ }^{32}$ BERTONI, 2001, p. 12. Tradução: “os imigrantes não eram somente mão de obra vital para uma economia em expansão, estrangeiros esses deveriam integrar se a uma sociedade com diferentes graus de integração e conflito, sendo potenciais cidadãos de um sistema político em gestação e de uma nação que estava se formando como também, e ao mesmo tempo, eram membros de outras nações diferentes, que também estavam em formação."

${ }^{33}$ SUEZ, 2006, p. 131. Tradução: "Era domingo e Lucien andou um pouco pelo porto. Ele olhou para um navio de passageiros de bandeira italiana atracado em uma das docas."

${ }^{34}$ SUEZ, 2006, p. 131. Tradução: “que trabalhava no matadouro. [E que] Falou de seu empregador, como se Lucien o conhecesse. Disse que eu era um italiano piolhento e que não me pagaria um centavo. Luigi Melle, os olhos fixos no rosto de Lucien, esclareceu: Dio cane...! Se eu sou um italiano piolhento, ele não passa de um avarento holandês."
} 
Temos, nessa obra também, a presença de outros imigrantes, ainda que lateralmente, percebese que há na cidade grupos diversos. E, ainda, não apenas grupos diversos senão também grupos que ocupam diferentes lugares no tecido social, como o que se passa com os ingleses em "Complot" (a outra novela d Trilogía).

Luigi ingressa no movimento operário e Lucien sempre que pode se afasta do envolvimento na política que pode ser perigoso e é assim, mesmo sem qualquer participação nos movimentos das greves que ocasionaram a que ficou conhecido como Semana Trágica de $1919^{35}$, é preso e torturado: “QQué había hecho yo, para que ese hombre me castigara de ese modo?”, ${ }^{36}$ pensa Lucien.

O excesso de violência e o preconceito em relação ao imigrante, especialmente ao judeu, ao camponês, estão marcadas na passagem abaixo:

Tu padre vino de Rusia y pasó por el Hotel de Inmigrantes en 1898. En ese hotel había gente sucia y ruidosa...

El tono de su voz subió,

$Y$ ahora, tengo frente a mí, a su hijo, un revoltoso ferroviario, que se aloja en "nuestra pensión", desde la madrugada del 10 de enero de 1919, y que va a explicarme de dónde sacó su padre ese nombre que le puso: Lucien. Qué nombre para un campesino...

[El hombre de la Guardia Cívica (...)] Hacía comentarios sobre los judíos, sobre los anarquistas y sobre los italianos. ${ }^{37}$

Nesse exercício de leitura, o passado atravessa as obras e ele aparece, em cada uma delas, trançando-se com as memórias, com os processos de imigração e sentimentos de estrangeireidades,

\footnotetext{
${ }^{35}$ Um breve contexto: "[No dia sete de janeiro,] Em Buenos Aires a tarde foi extremamente calorosa. Os termômetros registraram ao meio-dia $38^{\circ} \mathrm{C}$, com a umidade relativa do ar chegando a $80 \%$, o que contribui ainda mais para o desconforto térmico. /Neste dia, ao redor das 15h45, pela Avenida Amancio Alcorta, cinco carroças da empresa metalúrgica Vasena realizavam o trajeto entre o depósito de materiais no bairro de Nueva Pompeya e suas oficinas localizadas na esquina das ruas Cochabamba e Rioja. Em decorrência da conflituosa greve dos operários metalúrgicos dessa empresa (que reivindicavam 12\%de aumento e redução de horas de trabalho) e que se estendia desde o fim de 1918, seu dono, Pedro Vasena, a pedido do chefe de polícia [...], havia mudado o itinerário das carroças para que estas não passassem perto da sede dos Metalúrgicos Unidos. [...] / Porém, segundo o relato de La Prensa, um grupo de grevistas, no horário acima indicado, atacou a formação na esquina da Rua Pepiri com a Avenida Alcorta. Perto dali já estava postado dentro de um prédio da central telefônica um grupo de bombeiros armados com fuzis mauser e que, ainda segundo o jornal, faziam a guarda deste edifício que nos dias anteriores teria sido destruído pelos grevistas para impedir as comunicações do depósito com os escritórios Vasena. Os bombeiros, então, abriram fogo conta os grevistas" (FERREIRA, 2014, p. 110-111)

${ }^{36}$ SUEZ, 2006, p. 160. Tradução: "O que teria feito eu para que esse homem me castigasse desse modo?

${ }^{37}$ SUEZ, 2006, p. 155. Tradução: "Seu pai veio da Rússia e passou pelo Hotel Imigrantes, em 1898. Nesse hotel, havia pessoas sujas e barulhentas... / O tom de sua voz aumentou, / E agora, tenho na minha frente, seu filho, um ferroviário revoltoso, que se aloja na "nossa pensão", desde as primeiras horas de 10 de janeiro de 1919, e que vai me explicar de onde seu pai tirou esse nome que ele pôs, Lucien. Que nome para um camponês... / [O homem da Guarda Civil (...)] Fazia comentários sobre os judeus, sobre os anarquistas e sobre os italianos."
} 
com a tradição e a diáspora judaicas, com os processos de construção de identidades e sentimentos de pertencimentos para a formação de cada uma das tramas. São narrativas que abordam uma memória tanto individual quanto coletiva, que estão relacionadas ao processo de construção de um sentimento de identidade, de pertencimento. E, ainda, se ficarmos apenas com a novela El arresto, temos a presença do mesmo evento histórico, a Semana Trágica de 1919.

Se temos em Orgambide, uma recuperação da visão de Gerchunoff, ao reconstruir a origem da figura do gacho judío da mescla do imigrante com os nativos, valorizando, de forma otimista, a vida no campo, em Perla Suez, não há em nenhuma das novelas da trilogia qualquer cena idílica sobre o campo que é devastado por tempestades, fica lamacento, apodrece e é assolado por pestes. Por outro lado, a aproximação de Suez a Gerchunoff pode ser configurada a partir do fato de que suas obras se concentram em temáticas provenientes da experiência rural e não da urbana.

Bibliografía

BERTONI, Lilia Ana. Patriotas, cosmopolitas y nacionalistas: la construcción de la nacionalidad argentina a fines del siglo XIX. Buenos Aires: Fondo de Cultura Económica de Argentina, 2001. CAPELATO, Maria Helena Rolim. “Intelectuais latino-americanos: o 'caráter nacional' em questão". In: Anos 90, Porto Alegre, v.15, n.28, jul.2009, Disponível em: https://seer.ufrgs.br/anos90/article/view/10241. Acesso em: dez. 2019.

FEIERSTEIN, Daniel, El genocidio como práctica social. Entre el nazismo y la experiencia argentina. Buenos Aires: Fondo de Cultura Económica, 2014.

FERREIRA, Fernando Sarti. Triênio trágico: flutuações econômicas e conflito social em Buenos Aires, 1919-1921 (Dissertação de Mestrado) São Paulo: Faculdade de Filosofia Letras e Ciências Humanas da Universidade de São Paulo, 2014.

FINCHELSTEIN, Federico. La Argentina fascista: los orígenes ideológicos de la dictadura. Buenos Aires: Sudamericana, 2012 (ebook).

FREIDENBERG, Judith. La invención del gaucho judio: Villa Clara y la construcción de la identidad argentina. Buenos Aires: Promeyeo Libros.

GERCHUNOFF, Alberto Los gauchos judíos. Buenos Aires: Colihue: Biblioteca Nacional, 2007.

LEVI, Primo. É isto um homem? Rio de Janeiro: Editora Rocco, 1988. 
ORGAMBIDE, Pedro. Hacer la América. Buenos Aires: Bruguera, 1984.

PINTO, Júlio Pimentel. Uma memória do mundo: ficção, memória e história em Jorge Luis Borges. São Paulo: Estação Liberdade: FAPESP, 1998.

SACCOMANNO, Guillermo. "Tzures”. In: SUEZ, Perla. Trilogía de Entre Ríos. Buenos Aires: Grupo Editorial Norma, 2006, p. 09-11.

SARMIENTO, Domingo Faustino. Facundo ou civilização e barbárie. São Paulo: Cosac Naify, $2010 /$

SINAI, Javier. Los crímenes de Moisés Ville: una historia de gauchos y judíos. Buenos Aires: Tusquets Editores, 2013.

SOUZA, Gustavo Augusto. Representação da memória e da imigração em Trilogía de Entré Ríos. (Dissertação de Mestrado) São Paulo: Faculdade de Filosofia Letras e Ciências Humanas da Universidade de São Paulo, 2017.

SOSNOWSKI, Saúl. “Fronteras en las letras judías-latinoamericanas”. In: Revista Iberoamericana. Vol. LXVI, Núm. 191, 2000. Disponível em: https://revistaiberoamericana.pitt.edu/ojs/index.php/Iberoamericana/article/viewFile/5765/5911. Acesso em: fev. 2020.

SUEZ, Perla. Trilogía de Entre Ríos. Buenos Aires: Grupo Editorial Norma, 2006. 